\title{
Hubungan antara Dukungan Sosial dan Kesiapan Kerja pada Siswa SMK Setia Darma Palembang
}

\author{
Eka Agustia Ningsih ${ }^{a *}$, Ema Yudiani $^{b}$, Dwi Despiana ${ }^{c}$ \\ ${ }^{a, b, c}$ Universitas Islam Negeri Raden Fatah Palembang \\ *Corresponding author: ekaagustianingsih020@gmail.com
}

\begin{abstract}
Abstrak
Penelitian ini bertujuan untuk mengetahui apakah ada hubungan dukungan sosial dengan kesipan kerja pada siswa kelas XII SMK Setia Darma Palembang. Dengan menggunakan penelitian kuantitatif. Sampel yang digunakan dalam penelitian berjumlah 172 siswa. Metode analisis data yang digunakan adalah analisis product moment. Berdasarkan hasil penelitian yang telah dilakukan, maka dapat disimpulkan bahwa ada hubungan yang signifikan antara dukungan sosial dengan kesiapan kerja, hal ini dibuktikan dengan nilai hasil koefisien korelasi yang menunjukkan angka 0,409, dengan nilai sig. 0,000 dimana $\mathrm{p}<0,05$, artinya semakin tinggi dukungan sosial maka semakin tinggi pula kesiapan kerja, sebaliknya semakin rendah dukungan sosial maka semakin rendah kesiapan kerja siswa.
\end{abstract}

\section{Kata Kunci}

Dukungan sosial, Kesiapan kerja; Siswa SMK

\begin{abstract}
This study aims to determine whether there is a relationship of social support with work readiness in class XII students of SMK Setia Darma Palembang. By using quantitative research. The sample used in the study amounted to 172 students. Data analysis method used is product moment analysis. Based on the results of research that has been done, it can be concluded that there is a significant relationship between social support and work readiness, this is evidenced by the results of the correlation coefficient which shows the number 0.409, with a sig. 0,000 where $p<0.05$, meaning that the higher the social support, the higher the job readiness, conversely the lower the social support, the lower the work readiness of students.
\end{abstract}

\section{Keywords}

Readiness for work; Social support; Students 


\section{Pendahuluan}

$\mathrm{P}$ endidikan mempunyai peran yang sangat penting untuk menjamin perkembangan dan kelangsungan kehidupan suatu bangsa (Budiyono, 2014). Pendidikan Menengah Kejuruan (SMK) menurut Peraturan Pemerintah Nomor 29 Tahun 1990 merupakan jenjang pendidikan menengah yang mengutamakan pengembangan kemampuan peserta didik untuk dapat melaksanakan jenis pekerjaan tertentu. Merujuk pada Undang-Undang Nomor 20 Tahun 2003 tentang Sistem Pendidikan Nasional, tujuan pendidikan kejuruan merupakan memepersiapan peserta didik untuk dapat berkerja pada suatu bidang tertentu, sebagai tenaga kerja tingkat menengah sesuai dengan keahlian dan keterampilan yang dimiliki. Oleh karena itu, peserta didik dengan Sekolah Menengah Pertama (SMK) diharapkan mampu berkerja dan mengembangkan diri secara profesional dan mandiri sesuai dengan kompetensi yang dimiliki. Tetapi pada kenyataan di lapangan dari hasil wawancara, penulis menemukan bahwa belum semua lulusan SMK dapat memenuhi tuntutan dunia kerja sesuai dengan keahlian dan keterampilannya. Hal ini karena adanya kesenjangan antara keterampilan yang dimilki oleh lulusan dengan keterampilan yang dibutuhkan di dunia kerja. Hal ini dapat dilihat dari data jumlah pengangguran lulusan SMK yang ada di Indonesia.

Berdasarkan hasil pendataan yang dilakukan oleh Badan Pusat Statistik (BPS) mencatat pengangguran terbuka pada Agustus 2019 berjumlah 7,05 juta orang, hal ini meningkat dari Agustus 2018 yang hanya 7 juta orang. Hal ini didominasi oleh lulusan Sekolah Menengah Kejurusan (SMK) sebesar 10,42\% (Kompas.com). Sedangkan angka pengangguran di Provinsi Sumatera Selatan dari data Badan Pusat Statistik (BPS) Sumsel tercatat hingga Agustus 2019 tingkat pengangguran dari lulusan SMK mencapai 11, 69\% atau sekitar 37 ribu orang dari total angka pengangguran

(Liputan6.com). Permasalahan ini sama halnya dengan apa yang terjadi di salah satu SMK swasta yang telah memiliki akreditadi A yang berada di Sumatera Selatan tepatnya di kota Palembang. Berdasarkan dari hasil wawancara pada salah satu guru di SMK tersebut maka mendapatkan hasil bahwa di SMK tersebut pada setiap tahunnya meluluskan kurang lebih 300-400 siswa. Siswa yang langsung berkerja setelah lulus sekolah sesuai dengan jurusan saat SMK atau keterampilan yang dimiliki 12\%, siswa yang berkerja tidak sesuai dengan jurusan saat SMK yaitu 28\%, siswa yang melanjutkan pendidikan ke jenjang yang lebih tinggi yaitu 25\% Sedangkan tingkat pengangguran yang mencapai $35 \%$.

Merujuk penjelasan diatas, banyaknya pengangguran lulusan SMK harus diselesaikan secara cepat. Hal yang harus dilakukan yaitu memperbaiki sistem pendidikan agar siswa SMK memiliki kriteria yang dibutuhkan di dunia kerja dan seharusnya siswa SMK mencari tahu penyebab terjadinya banyak pengagguran pada lulusan SMK, dan mencari solusi yang terbaik agar tidak menjadi pengangguran saat setelah lulus SMK. Salah satu solusi untuk membuat siswa setelah lulus sekolah bisa dapat langsung dapat bekerja, siswa harus memliki pengetahuan, keterampilan dan memiliki potensi-potensi yang harus dibutuhkan untuk suatu bidang pekerjaan tertentu. 
Kesiapan kerja adalah kesediaan individu untuk dapat melakukan suatu pekerjaan tertentu yang didukung dengan pengetahuan, keterampilan dan sikap kerja serta potensi-potensi peserta didik dalam bidang pekerjaan tertentu. Brady (2010) seseorang memiliki kesipan kerja yang baik harus memiliki aspek-aspek kesiapan kerja yaitu responsibility, fleksibility, skills, communication, self view dan health \& savety. Kesiapan kerja merupakan salah satu aspek penting sebelum siswa terjun ke dunia kerja karena bila siswa tidak mampu dan tidak memiliki kesiapan kerja maka siswa tersebut tidak dapat melakukan tugasnya dengan baik. Hersey dan Blanchard (2008) berpendapat bahwa saat individu merasa tidak mampu dan tidak memiliki kesiapan kerja akan menyebabkan individu tidak dapat melakukan tugasnya dengan baik, tidak mampu memimpin, terjadinya prokrastinasi, tidak menyelesaikan tugas, sering bertanya mengenai tugas, menghindari tugas, dan merasa tidak nyaman.

Berdasarkan permasalahan yang dijelaskan diatas sesuai dengan temuan kasus oleh peneliti yang dilakukan kepada tiga siswa dengan berinisial S, A dan R di SMK Setia Darma Palembang pada 19 Desember 2019. Hasil wawancara yang didapatkan bahwa siswa SMK belum memiliki banyak pengetahun yang cukup mengenai dunia pekerjaan, keterampilan yang dimiliki belum begitu baik untuk dunia kerja. Dalam dunia kerja kemampuan hart skill dan soft skil sangat dibutuhkan. Hal ini belum banyak dimiliki siswa, siswa belum mampu mengoperasikan komputer dengan baik, komunikasi yang dimiliki siswa juga belum begitu baik terkadang masih kurang percaya diri, merasa ragu akan kemampuan diri sendiri, belum mampu mengemukan pendapat didepan umum, dan belum memiliki kerja sama yang baik. Siswa juga belum memiliki tanggung jawab yang baik terkadang masih ikut-ikutan teman. Faktor pendorong siswa akan berkerja karena adanya dorongan dari teman, keluarga dan lingkungan sekitarnya.

Selanjutnya, peneliti juga melakukan wawancara dengan dua guru wali kelas pada tanggal 21 Februari 2020. Hasil wawancara yang didapatkan peneliti bahwasannya siswa kelas XII SMK Setia Darma Palemabang masih ada siswa yang belum memiliki tanggung jawab yang baik, seperti tidak mengerjakan tugas dan tidak ikut mengerjakan tugas kelompok. Siswa juga belum mampu berinteraksi dengan baik saat bertemu orang-orang baru, interaksi yang dilakukan siswa didalam kelas pun terkadang jarang terjadi, komunikasi juga belum belum begitu baik, keterampilan yang dimiliki siswa juga belum begitu banyak didapat disekolah karena keterbatasan oleh waktu tetapi sekolah akan menyalurkan siswa yang memiliki potensi ke perususahaan atau instansi yang cocok untuk siswa tersebut.

Kesiapan kerja siswa tidak bisa terbentuk dengan sendirinya menurut Sukardi (1987) faktor-faktor yang mempengaruhi kesiapan kerja terbagi menjadi dua faktor yaitu faktor yang bersumber dari individu dan faktor sosial. Faktor dalam diri individu yaitu kemampuan intelegensi, minat, bakat, sikap, kepribadian, nilai, hobi atau kegemaran, prstasi, keterampilan, penggunaan waktu senggang, aspirasi dan pengetahuan sekolah atau pendidikan sambungan, pengetahuan tentang dunia kerja, pengalaman kerja, kemampuan dan keterbatasan fisik dan penampilan lahiriah, masalah dan keterbatasan pribadi. 
Sedangkan faktor sosial yaitu dukungan dan pengaruh orang tua, teman sebaya dan masyarakat sekitar. Baron dan Byrne (2005) mendefinisikan dukungan sosial sebagai kenyamanan fisik dan psikologis yang diberikan oleh teman-teman dan keluarga individu tersebut.

Pada tanggal 9 maret 2020 di SMK Setia Darma Palembang penulis melakukan studi pendahuluan lagi. Penulis mendapatkan hasil bahwa siswa tidak mendapatkan dukungan secara psikologis dari orang tua siswa karena sibuk berkerja. Selain itu siswa tentunya dipengaruhi oleh teman sebayanya yang akan berkerja sehingga siswa ikut-ikutan untuk berkerja. Selain itu siswa belum mendapatkan dukungan dari lingkungan tempat siswa berada, terutama lingkungan rumah atau lingkungan bermain siswa yang tidak memperdulikan kesiapan kerja yang dimiliki siswa tersebut.

Selanjutnya peneliti juga melakukan wawancara dengan orang tua siswa yang berinisial $\mathrm{N}$ pada tanggal 10 maret $2020 \mathrm{di}$ rumah siswa yang bertepat di Plaju. Dari hasil wawancara yang didapat oleh peneliti bahwasanya $\mathrm{N}$ sangat mendukung keputusan anaknya saat nanti akan berkerja atau akan melanjutkan ke jenjang Universitas. $\mathrm{N}$ juga mengaku bahwa hanya memberi dukungan secara materil yaitu dengan memberikan sesuatu hal yang anak butuhkan untuk kepentingan sekolahnya. Sedangkan dukungan psikologis sangat kurang karena $\mathrm{N}$ sibuk berkerja.

Berdasarkan hasil wawancara diatas maka dapat disimpulkan bahwa kesiapan kerja siswa SMK Setia Darma Palembang dipengaruhi oleh dukungan yang didapatkan siswa baik dari keluarga, teman dan lingkungan sekitar. Diperkuat dengan penelitian yang dilakukan oleh Sari (2017) memperoleh hasil bahwa terdapat hubungan positi dan signifikan antara dukungan sosial dengan kesiapan kerja pada siswa SMK. Dukungan dari teman sebaya tak kalah pentingnya, karena remaja cenderung lebih banyak menghabiskan waktu dengan teman sebaya. Munerut Hurlock (2004) remaja lebih banyak berada diluar rumah bersama dengan teman-teman sebaya sebagai kelompok, maka dapatlah dimengerti bahwa pengaruh teman-teman sebaya pada sikap, pembicaraan, minat, keterampilan dan perilaku.

Berdasarkan uraian latar belakang diatas, maka penulis tertarik untuk melakukan penelitian dengan mengangkat permasalahan diatas karena jika ini dibiarkan begitu saja maka pengangguran di Indonesia semakin menjamur. Maka itu peneliti ingin mengetahui lebih lanjut mengenai hubungan antara dukungan sosial dengan kesiapan kerja siswa kelas XII SMK Setia Darma Palembang.

\section{Metode}

Penelitian ini bertujuan untuk mengetahui hubungan antara dukungan sosial dengan kesiapan kerja siswa kelas XII SMK Setia Darma Palembang. Oleh karena itu, penelitian ini menggunakan pendekatan kuantitatif korelasional. Penelitian kuantitatif adalah penelitian yang menekanan analisisnya pada data-data kuantitatif (angka) yang dikumpulkan melalui prosedur pengukuran dan diolah dengan metode analisis statistika. Semuavariabel yang terlibat harus diidentifikasikan dengan jelas dan terukur (Azwar, 2017). 


\section{Partisipan}

Populasi adalah keseluruhan subjek penelitian (Arikunto, 2013). Populasi dalam penelitian ini adalah siswa kelas XII SMK Setia Darma Palembang yang berjumlah 340 siswa.

Sampel adalah bagian dari jumlah dan karakteristik yang dimiliki oleh populasi tersebut (Sugiyono, 2017). Teknik pengambilan sampel pada penelitian ini, peneliti menggunakan tabel pengambilan sampel yang dikembangkan oleh Isaac dan Michael. Pada taraf kesalahan 5\% didapatkan 172 subjek dari populasi 340 siswa kelas XII SMK Setia Darma Palembang. Teknik yang digunakan dalam penelitian ini adalah teknik cluster random. Cluster random sampling dilakukan dengan cara rendomisasi terhadap kelompok, bukan terhadap subjek penelitian secara individu (Azwar, 2017).

\section{Prosedur dan Desain}

Pengumpulan data dalam kegiatan penelitian mempunyai tujuan untuk mengungkap fakta empirik mengenai variabel yang diteliti (Azwar, 2017). Metode pengumpulan data yang digunakan dalam penelitian ini adalah berupa skala yang ditujukan kepada subjek. Skala merupakan perangkat pertanyaan yang disusun untuk mengungkap atribut tertentu melalui respon terhadap pernyataan tersebut (Azwar, 2012).

\footnotetext{
Alat Ukur

Penelitian ini menggunakan dua skala psikologi, yaitu skala dukungan sosial dan skala kesiapan kerja. Model skala yang digunakan untuk meakukan penilaian skor pada setiap item skala psikologi dalam penelitian ini berupa skala Likert. Skala
}

Likert digunakan untuk mengukur sikap, pendapat, dan persepsi seseorang atau sekelompok orang tentang fenomena sosial. Dalam penelitian, fenomena sosial ini telah ditetapkan secara spesifik oleh peneliti, yang selanjutnya disebut sebagai variabel penelitian (Sugiyono, 2017).

Skala dukungan sosial terdiri dari 60 item pernyataan yang disajikan dalam bentuk kalimat favoriabel dan unfavorable. Sedangkan skala kesiapan kerja terdiri dari 64 item pernyataan yang disajikan dalam kalimat favorable dan unfavorable. Kedua skala ini memiliki 5 alternatif jawaban yang disediakan yaitu, SS (Sangat Sesuai), S (Sesuai), N (Netral), TS (Tidak Sesuai), dan STS (Sangat Tidak Sesuai).

\section{Analisis Data}

Sebelum dilakuakn analisis data, terlebih dahulu dilakukan uji asumsi prasyarat terhadap hasil penelitian yang meliputi uji hipotesis dan uji linieritas. Setelah dilakukan uji asumsi maka langkah selanjutnya yang dilakukan adalah uji hipotesis. Adapun teknik yang digunakan dalam uji hipotesis adalah analisis pearson product moment.

\section{Hasil}

Berdasarkan hasil deskripsi data penelitian dapat diuraikan mengenai kategorisasi masing-masing variabel penelitian. Penelitian ini menggunakan jenjang kategorisasi variabel penelitian berdasarkan skor empirik (mean dan standar deviasi). Hasil selengkapnya dapat dilihat dari skor empirik masing-masing variabel penelitian yang dapat dilihat pada tabel berikut ini: 
Tabel 1.

Deskripsi data penelitian

\begin{tabular}{lllll}
\hline Variabel & \multicolumn{4}{l}{ Skor X (empirik) } \\
\cline { 2 - 5 } & $\begin{array}{l}\text { X } \\
\text { Min }\end{array}$ & Max & Mean & SD \\
\hline $\begin{array}{l}\text { Dukungan } \\
\text { sosial }\end{array}$ & 135 & 211 & 181.05 & 16.389 \\
\hline $\begin{array}{l}\text { Kesiapan } \\
\text { kerja }\end{array}$ & 132 & 210 & 177.39 & 15.340 \\
\hline
\end{tabular}

Skor empirik pada tabel tersebut akan menjadi pedoman untuk membuat kategorisasi dari variabel penelitian. Peneliti telah membuat kategorisasi berserta frekuensi dari variabel penelitian dengan rumus kategorisasi yang dapat dilihat pada tabel dibawah ini:

Tabel 2.

Kategorisasi Skor Skala Dukungan Sosial

\begin{tabular}{llll}
\hline Skor & $\begin{array}{l}\text { kategorisas } \\
\text { i }\end{array}$ & N & $\begin{array}{l}\text { persentas } \\
\text { e }\end{array}$ \\
\hline $\mathrm{X} \leq 74$ & Rendah & 28 & $16 \%$ \\
\hline $\begin{array}{l}165<\mathrm{X} \leq \\
197\end{array}$ & Sedang & 108 & $63 \%$ \\
\hline $\mathrm{X}>197$ & Tinggi & 36 & $21 \%$ \\
\hline Total & & 172 & $100 \%$ \\
\hline
\end{tabular}

Berdasarkan perhitungan kategorisasi skor variabel dukungan sosial dapat disimpulkan bahwa terdapat 28 siswa atau $16 \%$ pada kategori rendah, 108 siswa atau $63 \%$ pada kategori sedang, dan sebanyak 36 siswa atau $21 \%$ pada kategori tinggi.

\section{Tabel 3.}

Kategorisasi Skor Skala Kesiapan Kerja

\begin{tabular}{llll}
\hline Skor & kategorisasi & N & Persentase \\
\hline$X \leq 162$ & Rendah & 23 & $13 \%$ \\
\hline $162<X \leq$ & Sedang & 119 & $69 \%$ \\
192 & & & \\
\hline$X>192$ & Tinggi & 30 & $18 \%$ \\
\hline Total & & 172 & $100 \%$
\end{tabular}

Berdasarkan perhitungan kategorisasi skor variabel kesiapan kerja dapat disimpulkan bahwa 23 siswa atau 13\% pada kategori rendah, 199 siswa $69 \%$ pada kategori sedang, dan 30 siswa atau $18 \%$ pada kategori tinggi pada siswa SMK Setia Darma Palembang.

\section{Uji Normalitas}

Uji normalitas yang digunakan untuk mengetauhui normalitas sebaran data penelitian. Kaidah yang digunakan untuk menentukan apakah data penelitian berdistribusi normal atau tidak jika angka signifikansi $\mathrm{p}>0,05$, maka dapat berdistribusi normal. Sedangkan jika nilai signifikansi $\mathrm{p}<0,05$, amka data berdistribusi tidak normal (Alhamdu, 2015).

\section{Tabel 4.}

Deskripsi Uji Normalitas

\begin{tabular}{lll}
\hline Variabel & $\begin{array}{l}\text { Kolmogorov- } \\
\text { Smirnov } \\
\text { Test }\end{array}$ & Ket \\
\hline $\begin{array}{l}\text { Dukungan } \\
\text { sosial }\end{array}$ & 0.069 & Normal \\
\hline $\begin{array}{l}\text { Kesiapan } \\
\text { kerja }\end{array}$ & 0.200 & Normal \\
\hline
\end{tabular}

Berdasarkan tabel deskripsi hasil normalitas maka dapat dipahami sebagai berikut:

1. Hasil uji normalitas terhadap variabel dukungan sosial memiliki nilai signifikansi sebesar 0.069 berdasarkan data tersebut $(\mathrm{p}=0.069>0,05)$ sehingga dapat dikatakan bahwa variabel dukungan sosial berdistribusi normal.

2. Hasil uji normalitas terhadap variabel kesiapan kerja memiliki nilai signifikansi sebesar 0.200 berdasarkan data tersebut $(\mathrm{p}=0.200>0,05)$ sehingga dapat dikatakan bahwa 
variabel kesiapan kerja berdistribusi normal.

\section{Uji Linieritas}

Uji linieritas digunakan untuk mengetahui apakah kedua variabel secara signifikan mempunyai hubungan linier atau tidak. Dengan mengguankan program SPSS versi 22 for windows uji linieritas menggunakan tes for linierity pada taraf signifikansi 0,05. Apabila nilai signifikansi pada Deviation from Linierity lebih besar dari 0,05 berarti kedua variabel memiliki hubungan yang linier (Alhamdu, 2015).

\section{Tabel 5.}

Hasil Uji Linieritas

\begin{tabular}{llll}
\hline Variabel & F & Sig & Ket \\
\hline Dukungan & 1.329 & 0.111 & Linier \\
sosial $><$ & & & \\
Kesiapan kerja & & & \\
\hline
\end{tabular}

Berdasarkan nilai signifikansi pada deviation from linierity adalah 0.111, verarti nilai signifikan lebih besar dari 0,05 maka dapat disimpilkan bahwa hubungan antara variabel dukungan sosial dengan variabel kesiapan kerja mempunyai hubungan yang linier $(0.111>0.05)$ dengan demikian uji asumsi linieritas terpenuhi.

\section{Uji Hipotesis}

Uji hipotesis ini digunakan untuk mengetahui hubungan antara variabel $\mathrm{X}$ dan variabel $Y$. dimana peneliti disini menggunakan perhitungan statistik adalah analisis korelasi pearson's product moment dengan menggunakan bantuan program SPSS versi 22 for windows. Hasil hipotesis antara kedua variabel tersebut dapat dilihatpada tabel berikut ini :
Tabel 6

Hasil Uji Hipotesis

\begin{tabular}{llll}
\hline Variabel & R & Sig & Ket \\
\hline $\begin{array}{l}\text { Dukungan } \\
\text { sosial }><\end{array}$ & 0.409 & 0.000 & Signifikan \\
Kesiapan & & & \\
kerja & & & \\
\hline
\end{tabular}

Berdasarkan hasil analisis diatas dapat diambil kesimpulan bahwa :

1. Dari tabel correlation menunjukan bahwa hubungan atau nilai koefisien korelasi antara variabel dukungan sosial dengan kesiapan kerja terbilang sedang yakni sebesar 0,409 .

2. Nilai signifikansi dari tabel didapat 0,000 dimana $(\mathrm{p}<0,05)$ maka $($ sig $=$ $0,000<0,05)$. Artinya hasil ini menunjukan adanya hubungan antara dukungan sosial dengan kesiapan kerja siswa kelas XII SMK Setia Darma Palembang. Menurut Sugiyono (2017) bahwa nilai korelasi 0,40-0,599 merupakan tingkat hubungan sedang, artinya hubungan dukungan sosial dengan kesiapan kerja yaitu kategori sedang.

3. Selanjutnya nilai r yang didapat positif, hal ini menunjukan bahwa antara dukungan sosial dengan kesiapan kerja memiliki hubungan yang positif. Apabila nilai pada salah satu meningkat, maka nilai pada variabel lainnya akan meningkat pula. Jadi dapat disimpulkan bahwa semakin tinggi dukungan sosal yang didapat siswa maka semakin tinggi pula kesiapan kerja yang dimiliki siswa. Sebaliknya jika rendahnya dukungan sosial yang didapat siswa maka semakin rendah pula kesiapan kerja yang dimiliki siswa. 


\section{Diskusi}

Hasil analisis dalam penelitian ini menggunakan teknik Korelasi Pearson's Product Moment diperoleh taraf signifikan sebsar 0,000 $(\mathrm{p}<0,05)$ berdasarkan hasil tersebut didapatkan bahwa hipotesis dalam penelitian ini diterima. Jadi dengan demikian bahwa dukungan sosial memiliki hubungan signifikan dengan kesiapan kerja pada siswa kelas XII SMK Setia Darma Palembang. Hal sependapat dengan Sari (2017) kesiapan kerja pada umumnya berasal dari orang-orang terdekat yaitu keluarga (orang tua), dukungan teman dan dukungan masyarakat sekitar.

Dilihat dari persentasi kategori kesiapan kerja sebanyak 13\% (23 siswa) yang memiliki kesiapan kerja pada tingkat rendah, 69\% (199 siswa) yang memiliki kesiapan kerja pada tingkat sedang, dan 18\% (30 siswa) yang memiliki kesiapan kerja pada tingkat tinggi. Hal tersebut dapat diartikan bahwa siswa kelas XII SMK Setia Darma Palembang rata-rata memiliki kesiapan kerja dengan kategori sedang dan hampir telam memenuhi aspek-aspke kesiapan kerja yang dikemukakan oleh Brady (2010) yaitu, tanggung jawa, fleksibililitas, keterampilan, komunikasi, pandangan terhadap diri dan kesehatan \& keselamatan.

Persentase dukungan sosial pada siswa kelas XII SMK Setia Darma Palembang terdapat $16 \%$ (28 siswa) pada kategori rendah, $63 \%$ (108 siswa) pada kategori sedang dan 21\% (36 siswa) pada kategori tinggi. Hal ini tersebut dapat diartikan bahwa siswa kelas XII SMK Setia Darma Palembang hampir memenuhi aspek-aspek dukungan sosial yang telah dikemukan oleh
Smet (2004) yaitu emosional, instrumental, informatif dan penghargaan.

Kategorisasi yang telah dijelaskan diatas maka dapat disimpulkan bahwa siswa kelas XII SMK Setia Darma Palembang memiliki dukungan sosial yang sedang sehingga kesiapan kerja yang dimiliki siswa pun menjadi sedang. Hal ini dibuktikan dengan analisis hipotesis terdapat nilai $\mathrm{r}$ sebesar 0,409 menurut Sugiyono (2012) termasuk kedalam kategori kotelasi sedang. Jadi terdapat hubungan yang sedang antara dukungan sosial dengan kesiapan kerja pada siswa kelas XII SMK Setia Darma Palembang.

Berdasarkan dari penjelasan diatas penelitian ini sama halnya dengan hasil penelitian terdahulu yang dilakukan oleh Lestari dan Siswanto (2015) mengenai pengaruh pengalaman prakerin, hasil belajar produktid dan dukungan sosial terhadap kesiapan kerja siswa SMK. Hasil yang didapat dalam penelitian ini menunjukan bahwa pengaruh pengalaman prakerin terhadap keispan kerja adalah sebesar 24\%, konstribusi hasil belajar prouktif terhadapan kesiapan kerja sebasar $3,8 \%$ dan dukungan sosial memiliki kontribusi terhadap kesiapan kerja sebesar 24\%. Maka dapat disimpulkan bahwa dukungan sosial memiliki kontribusi yang cukup besar dibandingkan dengan hasil belajar produktif. Dukungan sosial yang didapat oleh siswa akan membentuk karakter dan sikap siswa. Dukugan sosial yang baik terhadap siswa yang akan berkerja akan membuat siswa menjadi lebih percaya diri dalam memilih dan menentukan jenis pekerjaan yang akan digelutinya setelah lulus dari SMK. 
Penelitian ini juga selaras dengan yang dilakukan oleh Sari (2017) mengenai hubungan antara dukungan sosial dengan kesiapan kerja siswa SMK. Hasil penelitian ini menyatakan bahwa adanya hubunan yang positif dan signifikan antara dukungan sosial dengan kesiapan kerja pada siswa SMK Farmasi Samarinda dengan hasil koefisien korelasi Rank Spearman sebesar 0,268 dengan signifikansi sebesar 0,006, oleh karena nilai signifikan $<0,050$ maka hipotesisnya diterima, adanya hubungan antara dukungan sosial dengan kesiapan kerja siswa. Terdapat hubungan positif signifikan antara dukungan sosial dengan kesiapan kerja. hal ini dapat diartikan semakin tinggi dukungan sosial maka semakin tinggi pula kesiapan kerja yang dimiliki oleh siswa SMK Farmasi Samarinda. Maka sebaliknya, semakin rendah dukungan sosial maka semakin rendah pula kesiapan kerja yang dimiliki siswa SMK Farmasi Samarinda.

Sukardi (1987) menyebutkan bahwa salah satu faktor yang mempengaruhi kesiapan kerja yaitu pengaruh/dukungan orangtua, dukungan teman sebaya dan lingkungan sekitar. Menurut Baron dan Byrne (2005) mengartikan dukungan sosial merupakan sebagai kenyamanan fisik dan psikologis yang diberikan oleh keluarga, teman dan lingkungan sekitar individu tersebut.

Dukungan sosial yang sangat mempengaruhi kesiapan kerja siswa SMK umumnya berasal dari orang-orang terdekat seperti keluarga terutama orang tua, teman sebaya dan masyarakat sekitarnya. Keluarga adalah tempat pertama anak belajar. Menurut Sarafino \& Smith (2011) dukungan orang tua pada dasarnya ada dua macam diantaranya yaitu: 1) dukungan moral dari orang tua terhadap pendidikan anaknya dapat berupa perhatian terhadap pemenuhan kebutuhan psikis yang diantaranya kasih sayang, keteladanan, bimbingan dan pengarahan, dorongan, menanamkan rasa percaya diri dan lain sebagainya. 2) dukungan material seperti dukungan pemenuhan kebutuhan fisik dalam pendidikan, yaitu seperti membayar uang sekolah, fasilitas belajar, alat dan keperluan sekolah. Hal ini sangat berkaitan dengan kondisi ekonomi keluarga itu sendiri.

Dengan perhatian orang tua diharapkan dapat memberikan semangat belajar dan berusaha untuk meraih prestasi dan cita-cita anak. Hal lain yang dapat dilakukan orang tua yaitu mengingatkan anaknya ketika mendapatkan tugas yang harus diselesaikan dirumah, memantau aktivitas anak selama dirumah dan mengenai aktivitas belajar dan pergaulannya. Ketika adanya perhatian tersebut tentunya akan mempermudah pengawasan orang tua serta akan menimbulkan hubungan yang baik diantara anak dengan orang tua. Pada akhirnya anak akan berkembang dengan sempurna baik mental, emosi, dan fisiknya. Dukungan moral disini juga dapat dijadikan bahan masukan bagi anak SMK ketika ingin melanjutkan ke jenjang yang lebih tinggi. Jika anak akan memasuki dunia kerja hal ini dapat sebagai pembentuk mental yang siap untuk siap terjun kedunia kerja. Sedangkan jika anak ingin melanjutkan ke jenjang pendidikan lebih tinggi yaitu kuliah maka dukungan moral ini selain membentuk mental, dukungan moral juga dapat menjadi bahan masukan untuk menentukan jurusan seta perguruan tinggi yang akan dipilihnya. Penelitian yang dilakukan oleh Firdaus (2012) memperoleh hasil analisis korelasi parsial dan regresi sederhana antara dukungan keluarga terhadap kesiapan kerja 
siswa SMK di Kabupaten HSU, menunjukan hubungan positif 0,478 dan signifikan 0,000. Maka dapat dikatakan bahwa dukungan sosial keluarga memiliki hubungan dengan kesiapan kerja yang dimiliki siswa SMK di Kabupaten HSU.

Dukungan dari teman sebaya tak kalah penting dibanding dengan dukungan dari keluarga, karena remaja cenderung lebih banyak menghabiskan waktunya berada diluar rumah bersama dengan kelompok sosialnya, maka dapat dikatakan bahwa teman sebaya dapat memberikan pengaruh kepada anak baik sikap, pembicaraan, minat, penampulan dan perilaku (Hurlock, 2004). Jika anak berada pada lingkungan temanteman sebaya yang memiliki minat berkerja yang tinggi maka secara tidak sadar anak akan merasa tertarik dan ikutikutan dengan minat dari teman-temannya tersebut. Begitupun sebaliknya jika anak berada pada lingkungan teman-teman sebaya yang memiliki minat kerja yang rendah, maka anak juga akan mengikuti dan terpengaruh oleh teman-teman sebayanya.

Dukungan guru juga tak kalah penting dalam pengaruhnya terhadap kesiapan kerja seorang siswa. Menurut Sukardi (1987) salah satu tugas atau peran guru pembimbing yaitu mengidentifikasikan berbagai kebutuhan dan masalah siswa yang berkaitan dengan pelaksanaan program bimbingan karir disekolah. Guru akan memberikan arahan, nasihat, masukan-masukan sesuai dengan bidang yang diminati siswa itu sendiri. Dengan adanya guru pembimbing maka siswa akan merasa lebih siap untuk memasuki dunia keja karena dengan adanya guru pembimbing anak dapat menanyakan mengenai hal-hal yang belum diketahui mengenai dunia pekerjaan, masalah- masalah yang sedang dihadapi, dan anak merasa dirinya menjadi siap untuk berkerja dengan adanya pengetahuan tentang dunia pekerjaan.

Lingkungan memiliki peran penting dalam kesiapan kerja individu. Misalnya, lingkungan masyarakat pekerja tidak ada satu pun warga, baik tua maupun muda, laki-laki ataupun perempuan yang menganggur atau santai- santai saja, maka kondisi yang demikian ini akan mempengaruhi perilaku, sikap dan tindkan seseorang. Jika individu berada dalam lingkungan masyarakat demikian, baik secara langsuang maupun tidak langsung individu terpengaruh juga, paling tidak individu merasa malu jika tidak berkerja atau menganggur. Dengan adanya dukungan dari lingkungan tempat tinggal siswa merasa diperhatian dan diperdulikan sehingga membuatnya menjadi percaya diri untuk memasuki dunia kerja (Kardimin, 2004).

Agama Islam menjelaskan berkerja merupakan perintah Allah SWT dan menjadi Sunnah Rasulullah SAW, maka untuk sebagai calon tenaga kerja harus memiliki kesiapan kerja yang matang agar memperoleh pekerjaan yang diridhoi Allah SWT.

Firman Allah SWT dalam Surat At-Taubah ayat 105:

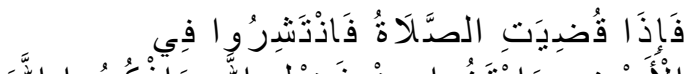

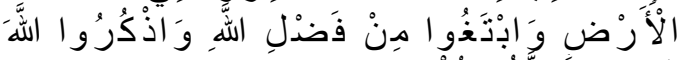

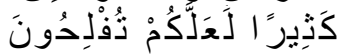

$$
\begin{aligned}
& \text { Artinya:"Dan Katakanlah: } \\
& \text { "Bekerjalah kamu, maka Allah dan } \\
& \text { Rasul-Nya serta orang-orang }
\end{aligned}
$$


lalu diberitakan-Nya kepada kamu apa yang telah kamu kerjakan". (Kementrian Agama, 2012)

Islam memerintahkan manusia untuk berkerja dan mendapatkan ridho Allah SWT, tetapi sebagai manusia sosial tentunya harus memiliki hubungan baik dengan sesama manusia dan membantu seseorang ketika mengalami kesulitan. Berikut ini adalah ayat yang berhubungan dengan dukungan sosial yaitu QS. AlMaidah ayat 80 :

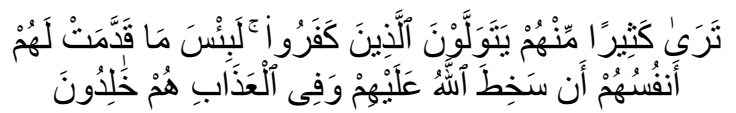

Artinya "Kamu melihat kebanyakan dari mereka tolong-menolong dengan orang-orang yang kafir (musyrik). Sesungguhnya amat buruklah apa yang mereka sediakan untuk diri mereka, yaitu kemurkaan Allah kepada mereka; dan mereka akan kekal dalam siksaan" (Kementrian Agama RI, 2012).

Berdasarkan hasil uraian yang telah dijelaskan maka dapat disimpulkan bahwa adanya hubungan yang signifikan anatar dukungan sosial dengan kesiapan kerja siswa kelas XII SMK Setia Darma Palembang. Sehingga hipotesis yang diajukan, bahwa ada hubungan antara dukungan sosial dengan kesiapan kerja pada siswa kelas XII SMK Setia Darma Palembang dapat diterima.

\section{Kesimpulan}

Berdasarkan hasil penelitian dan pembahasan, bahwa terdapat hubungan positif dan signifikan antara dukungan sosial dengan kesiapan kerja siswa kelas XII SMK Setia Darma Palembang. Hasil yang didapat dalam penelitian ini yaitu tingkat hubungan yang sedang, artinya hubungan dukungan sosial dengan kesiapan kerja pada kategori sedang. Hubungan yang positif pada variabel dukungan sosial dengan kesiapan kerja, maka dapat disimpulkan bahwa semakin tinggi dukungan sosial yang didapat siswa maka semakin tinggi pula kesiapan kerja yang dimilikinya. Sebaliknya semakin rendah dukungan sosial yang didapat siswa maka semakin rendah pula kesiapan kerja yang dimilikinya.

\section{Referensi}

Alhamdu. (2015). Analisis Statistik Dengan Program SPSS. Palembang: Noer Fikri.

Arikunto, S. (2013). Prosedur Penelitian Suatu Pendekatan Praktis. Jakarta: PT. Rineka Cipta.

Azwar, S. (2012). Penyusunan Skala Psikologi (rev. ed). Yogyakarta: Pustaka Pelajar.

Azwar, S. (2017). Metode Penelitian Psikologi (rev.ed). Yogyakarta: Pustaka Pelajar.

Baron, R.A, \& Byrne, D. (2005). Psikologi Sosial Jilid 2. Jakarta: Erlangga.

Brady, R.P. (2010). Work Readiness Inventory, Administrator Guide. JIBT Works.

Budiyono, K. (2014). Pancasila Untuk Perguruan Tinggi. Bandung: Alfabet.

Firdaus, Z. Z. (2012). Pengaruh Unit Produksi, Prakerin dan Dukungan Keluarga terhadap Kesiapan Kerja Siswa SMK. Jurnal Pendidikan Vokasi, 2 (3), 397-409.

http://www.bphn.go.id/data/documents/90 pp029.pdf.

Hurlock, B.E (2004). Psikologi Perkembangan. Jakarta: PT. Gelora. Aksara Pratama.

Inge, N. (2019, Agustus) Lulusan SMK Sumbang Angka Pengangguran Tertinggi di Sumsel. Liputan6 [online]. Diakses pada tanggal 19 
November 2019 dari https://www.liputan6.com/regional/ $\mathrm{read} / 4111105 /$ lulusan-

smksumbang-angka-penganggurantertinggi-di-sumsel.

Kardimin, A. (2004). Strategi Melamar Kerja dan Bimbingan Karir. Yogyakarta: Pustaka Pelajar.

Kementrian Agama RI. (2012). Al-Qur'an dan Tafsirnya. Jakarta: Kementrian Agama RI.

Lestari, I., \& Siswanto, B.T. (2015). Pengaruh Pengalaman Prakerin, Hasil Belajar Produktif dan Dukungan Sosial Keluarga Terhadap Kesiapan Kerja Siswa SMK. Jurnal Pendidikan Informatika dan Sains, 4(1), 60-77.

Peraturan Pemerintah Republik Indonesia Nomor 29 Tahun 1990. Diakses pada 30 November 2019.

Presiden Republik Indonesia. (2003). Undang-Undang Republik Indonesia Nomor 20 Tahun 2003. Diakses pada 20 November 2019. http://luk.staff.ugm.ac.id/atur/UU2 02003Sisdiknas.pdf

Sarafino, E.P,. \& Smith T.W. (2011). Health Psychology:

Biopsychosocial Interactions. United States of America: Jhon Willey \& Sons Inc.

Sari, E.R. (2017). Hubungan antara Dukungan Sosial dengan Kesiapan Kerja (Pada Siswa Kelas XII di SMK Farmasi Samarinda). Jurnal Psikoborneo, 5 (2), 353-367.

Smet, B. (2004). Psikologi Kesehatan. Jakarta: PT. Grasindo.

Sugiyono. (2017). Metode Penelitian Kuantitatif, Kualitatif, $R$ dan $D$. Bandung: Alfabeta.

Sukardi, D.K. (1987). Bimbingan Karir di Sekolah-Sekolah. Jakarta: Ghalia Indonesia

Ulya. F, N. (2019, November) Pengangguran Meningkat, Lulusan SMK Mendominasi. Kompas [online]. Diakses pada tanggal 19 November 2019 dari https://money.kompas.com/read/20 19/11/05/155358926/bps pengangguran-meningkat-lulusansmk-mendominasi. 